\title{
Teaching Special Decisions In A Lean Accounting Environment
}

Daniel Haskin, University of Central Oklahoma, USA

\begin{abstract}
Lean accounting has become increasingly important as more and more companies adopt the lean enterprise model or some variation of it. Cost and managerial accounting textbooks continue to use, almost exclusively, models based on standard overhead absorption, which if used in a lean environment will not accurately reflect the benefits from the movement to a lean enterprise and may distort the impact of the changes. Because of these developments, accounting students should be exposed to lean accounting models beyond a brief introduction in their basic cost and management accounting courses. This paper presents a model for teaching decision making in a lean company which uses value stream costing for such decisions as special orders and make-orbuy decisions. The use of these models in cost and managerial accounting classes will be of benefit to the future cost/managerial accountants.
\end{abstract}

Keywords: Lean Accounting, Cost Accounting, Special Decisions, Make-or-Buy Decisions, Special Orders, Just-in-Time Inventory, Target Costing.

\section{INTRODUCTION}

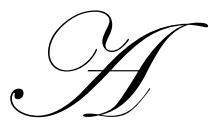

s more companies transition from traditional accounting systems to lean accounting systems, the need to focus on particular decision processes under lean accounting becomes more urgent. As discussed below, lean accounting is an entirely different method of collecting information and using information in decision processes than is traditional accounting. A review of cost and managerial accounting textbooks indicates that current textbooks give only a cursory exposure to lean accounting. For example, Horngren (2009) and Garrison (2010) discuss the basic principles of lean accounting along with the related topics of just-intime inventory and target costing, but no coverage is reserved for the actual application of the lean accounting principles for decision making.

\section{BACKGROUND}

Management accountants are for the most part trained to collect data and to make decisions based on traditional accounting systems such as full absorption costing or some modification of full costing such as variable costing. Traditional accounting systems were designed to support management principles like mass production and budgeting and focused on increasing shareholder value. Principles of lean accounting are very different from those of traditional accounting. Consequently, traditional accounting systems tend to cause behaviors that undermine the principles of lean accounting. To understand these behaviors, we need to review the basics of a lean accounting system.

Lean accounting changes the view that a company has of its customers because lean organizations seek to maximize the value created for the customer rather than maximizing shareholders' value. Consequently, lean accounting is not just a program to improve the traditional way of doing business, but is a new way of conducting business.

One of the fundamental differences between lean accounting and traditional accounting is that a lean organization is organized by value streams rather than by functions. A value stream is the sequence of processes through which a product is transformed and delivered to the customer. By design, a value stream spans multiple functions such as production, engineering, maintenance, sales and marketing, accounting, human resources, and 
shipping (IMA 2006). Value stream organization requires a basic reorganization of accounting information. The process changes from a forecast driven "push" environment to a customer driven "pull" environment where production is started only when the customer places an order. With the traditional forecast environment, product will be produced in line with the forecast or budget and stored until an order is received from a customer. Frequently, high inventory levels and even obsolescence may result. Traditional methods of allocating fixed manufacturing costs encourage forecasts for higher levels of production in order to spread the cost over more units and lower the unit cost.

The major differences between push and pull environments require a reassessment of the reports used by the company's decision makers. Departmental expense reports in a push environment are normally used by functional managers who are accounting for the costs that arise in their departments. In a value stream environment, the value stream manager and his/her team are the primary users of the financial information. The information is used for cost control and decision-making and is oriented to the value stream and not to functional departments. Unlike traditional full cost accounting, which absorbs all overhead costs into product costs and encourages overproduction, value stream organizations use simple summary direct costing with very little cost allocation. Consequently, lean accounting thinking is contrary to the traditional mindset that producing large batches to absorb overhead is efficient.

The philosophy of lean accounting's pull environment meshes very well with the philosophy of target costing. Target cost is the maximum cost that could be incurred on a product with the business still earning the desired profit margin at the targeted selling price. Using the traditional costing model, production costs are measured and the desired profit is added to set the selling price. Target costing considers the entire life cycle of a product, so the planning, development, and design stages of a product's life are important to the cost management process. Efficiency, which is one of the primary goals of lean production is of prime importance in target costing.

Lean accounting costs the value stream instead of products or other cost objects, so unit product costs are not calculated. Because most of our training and experience is in the role of traditional cost accountants, we may find it difficult to determine how many decisions can be made without standard product costs. Traditional income statements present information on cost of goods sold, applied overhead, and manufacturing variances, while value stream income statements emphasize material purchases, employee and equipment costs, and facility costs. Exhibit 1 (Adapted from IMA, 2006) presents a traditional income statement and contrasts it with a value stream statement. Notice that the top and bottom lines are the same on both statements. The difference is the way costs are assigned to value streams and the presentation of these costs. Most costs, especially labor and machine costs, are assigned directly to value streams using some simple cost driver, but such allocations are held to a minimum. Sustaining costs, which are necessary costs that support the entire facility, but cannot be directly associated with particular value streams, are not allocated to value streams, but are shown separately on the statements. Sustaining costs include management and support, facility costs, information technology, and human resource management costs that are not associated directly with a value stream.

One of the primary characteristics of lean accounting is the reduction of inventory to as low a level as possible. Most of us are familiar with tales of profit manipulation under traditional absorption costing created by absorbing fixed manufacturing costs into inventory when the inventory is not sold. This is possible because inventory changes affect profit using traditional accounting methods. The fixed manufacturing costs assigned to inventory will be reported as an asset rather than as an expense and net income will be increased by the amount of the fixed cost assigned to inventory. With lean accounting, the inventory changes are reported separately as belowthe-line adjustments and reported for the entire entity, not the separate value streams. This allows the value stream managers to assess their individual value streams without the complexities of the inventory changes affecting the value stream profit. If the company succeeds in adopting just-in-time inventory methods, the issue would largely disappear. Consequently, the motivation for manipulating inventory values also disappears.

The theory behind just-in-time inventory is to have materials needed in manufacturing at the precise moment they are needed in the manufacturing process. In order to accomplish this goal, a business must continuously seek ways to reduce waste and to enhance value for customers. These ideas are central to both just-intime inventory and lean manufacturing. Just-in-time makes production operations more efficient and cost effective 
and allows better customer response. Because materials are not needed until shortly before they are used in manufacturing, the cost of managing inventory is reduced considerably and may be eliminated entirely. This analysis is based on the assumption that the only relevant costs are the variable costs using the traditional definition. The fixed costs are made irrelevant because of the traditional cost assumption that absorbs all fixed costs into the regular production stream.

Under lean accounting, occupancy costs are actually assigned to value streams according to the amount of space used. Such items as utilities and property taxes are included here. Assignment of these costs provides motivation for the value stream teams to reduce occupancy costs. However, no attempt to absorb all of the occupancy costs is required. Space not used by a value stream is charged to sustaining costs. As a result, occupancy costs are handled in a similar manner to traditional accounting, but they are assigned to value streams instead of other cost objects such as products or divisions.

Exhibit 1

Functional and Value Stream Income Statements

Techsan Company

Functional Income Statement

\begin{tabular}{|c|c|c|c|c|}
\hline $\begin{array}{l}\text { Sales } \\
\text { Cost of Goods Sold } \\
\text { Gross Profit } \\
\text { Operating Expenses } \\
\text { Net Operating Income }\end{array}$ & & \multicolumn{3}{|c|}{$\begin{array}{r}\$ 100,000 \\
70,000 \\
30,000 \\
\quad 28,000 \\
\quad 2,000 \\
\end{array}$} \\
\hline \multicolumn{5}{|c|}{$\begin{array}{c}\text { Techsan Company } \\
\text { Value Stream(VS) Income Statement }\end{array}$} \\
\hline & VS 1 & VS 2 & Sustaining & Total Plant \\
\hline Sales & $\$ 60,000$ & $\$ 40,000$ & & $\$ 100,000$ \\
\hline Material Costs & 20,000 & 15,000 & \multirow{3}{*}{5,000} & 35,000 \\
\hline Employee Costs & 9,000 & 8,000 & & 22,000 \\
\hline Machine Costs & 10,000 & 5,000 & & 15,000 \\
\hline Occupancy Costs & 6,000 & 4,000 & \multirow[t]{2}{*}{5,000} & 15,000 \\
\hline Other Costs-VS & 1,000 & 1,000 & & 2,000 \\
\hline VS Profit & $\$ 14,000$ & $\$ 7,000$ & $\$(10,000)$ & $\$ 11,000$ \\
\hline \multicolumn{5}{|l|}{ Inventory Reduction } \\
\hline Plant Profit & & & & 14,000 \\
\hline Corporate Allocation & & & & 12,000 \\
\hline Net Operating Income & & & & $\$ \quad 2,000$ \\
\hline
\end{tabular}

\section{THE ISSUE-TEXTBOOK COVERAGE OF SPECIAL DECISIONS IN A LEAN ACCOUNTING ENVIRONMENT}

Cost and managerial accounting students should be exposed to more coverage of lean accounting than a cursory introduction to this topic. Two areas of coverage that would benefit students are accepting special orders and make-or-buy decisions in a manufacturing environment. These two special decision areas are covered in almost every existing cost or managerial accounting textbook. By placing coverage of lean accounting for these two special decisions close to the traditional coverage in textbooks, students will gain an increased understanding of both traditional accounting and lean accounting and how the two accounting techniques are similar and different. The following sections present a presentation that could be used to accomplish these goals.

\section{ACCEPTING SPECIAL ORDERS}

Managers often need to evaluate whether one-time orders that are not part of the company's normal ongoing business should be accepted. Using a traditional managerial accounting analysis, the manager would use a 
short-run, variable costing oriented decision format. For instance, Techsan Company receives a request to produce 200 units of a product at $\$ 17$ each. The normal selling price per unit is $\$ 22$ each and the unit product cost is $\$ 18$ as shown below:

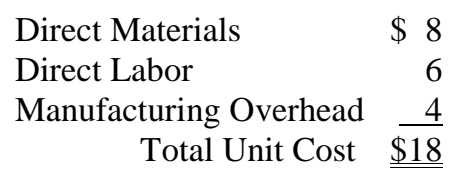

Based on the full cost analysis above, the company would decline the order because the offered price is below the unit cost. A traditional variable costing analysis would only consider the incremental costs and benefits as relevant. Analysis of the costs reveals that the variable portion of the manufacturing overhead is $\$ 1$ per unit. The order will have no effect on the fixed manufacturing overhead, but special equipment for the order will cost $\$ 200$.

Incremental Revenue

Incremental Costs

Variable Costs:

Direct Materials

Direct Labor

Variable Manufacturing $\mathrm{OH}$

Total Variable Costs $\frac{\text { Per Unit }}{\$ 17} \quad \frac{\text { Total }}{\$ 3,400}$

Fixed Cost

Total Incremental Cost

Special Equipment

\begin{tabular}{rr}
8 & 1,600 \\
6 & 1,200 \\
1 & 200 \\
\hline 15 & 3,000
\end{tabular}

Incremental Net Operating Income

200

$\$ 3,200$

$\$ 200$

The traditional analysis focuses on relevant costs. The relevant costs are the costs which would be different between the two alternatives: accept the special order or decline the special order. Direct material, direct labor, and variable manufacturing overhead would be seen as relevant costs and fixed manufacturing overhead would be seen as irrelevant because it would be incurred whether the order was accepted or not. Based on this analysis, the company should accept the special order because net income would be increased by $\$ 200$.

Analyzing the proposed sale from a value stream costing viewpoint yields an interesting contrast to a traditional analysis although not necessarily a different conclusion. Assume the product desired by Techsan Company would be produced in Value Steam 1 as indicated in Exhibit 1. The following table shows the effect on the value stream:

\begin{tabular}{lrrr} 
& $\frac{\text { Current }}{\$ 60,000}$ & With New Order & Change \\
\cline { 3 - 4 } Revenue & & $\$ 63,400$ & $\$ 3,400$ \\
Material Costs & 20,000 & 21,600 & 1,600 \\
Employee Costs & 9,000 & 9,000 & \\
Machine Costs & 10,000 & 10,200 & 200 \\
Occupancy \& Other & $\frac{7,000}{\$ 14,000}$ & $\frac{7,000}{\underline{\$ 15,600}}$ & $\underline{\underline{\$ 1,600}}$ \\
Profit & $\underline{\underline{23.61 \%}}$ & $1.28 \%$ \\
VS Profit \% & $23.33 \%$ & &
\end{tabular}

The changes reflect some new assumptions we make with lean accounting. Direct labor is included in employee costs and is viewed as a fixed cost. The cost of a team of employees in a value stream does not change until additional employees are needed. The existing employees are adequate to cover the increased production in 
our example, so the increased production does not increase employee costs. Based on this analysis, the order should be accepted because the value stream profit margin is increased $1.28 \%$.

\section{MAKE-OR-BUY DECISIONS}

Another important decision concerns whether to produce parts or other products internally or to buy the parts externally from a supplier. A traditional cost accounting analysis would use a short-run, variable costing analysis in much the same manner we illustrated for a special order. Consider the following example. Techsan Company is considering outsourcing a part that is produced and used in Value Stream 1. A traditional analysis reports the following costs of producing the part internally:

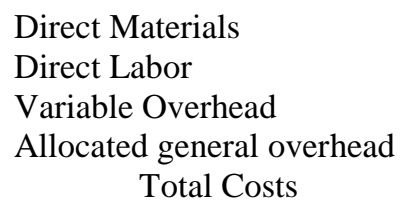

\begin{tabular}{crr} 
Per Unit & & 200 Units \\
\hline$\$ 7$ & & $\$ 1,400$ \\
8 & & 1,600 \\
1 & & 200 \\
3 & & 600 \\
$\$ \underline{\underline{\$ 19}}$ & & $\underline{\underline{3,800}}$
\end{tabular}

An outside supplier has offered to sell Techsan 200 units of the product at a price of $\$ 19$ each. A quick comparison to the full cost analysis above would show no effect on profit as the cost to make is $\$ 19$ per unit. A traditional variable costing analysis renders the following results:

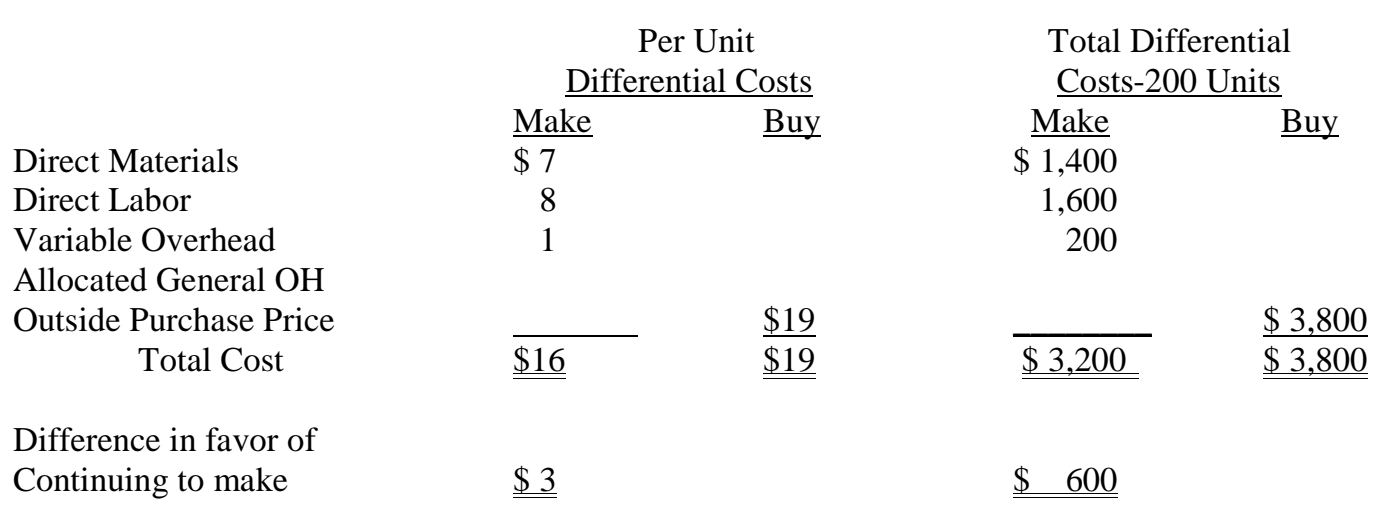

The traditional variable costing analysis follows the same line of reasoning as noted earlier for the special order decision. Direct materials, direct labor, and variable manufacturing overhead are seen as relevant costs while fixed manufacturing overhead is regarded as irrelevant because it would be incurred no matter what decision was made to make or buy. Based on this analysis, Techsan Co. should continue to make the part instead of contracting with an outside supplier.

In a lean environment, the above cost would be included in Value Stream 1 costs. Direct materials are included in material costs, direct labor is included in employee costs, and variable overhead is included in machine costs. A value stream analysis yields the following results:

\begin{tabular}{lrr} 
& $\underline{\text { Make }}$ & \multicolumn{1}{c}{ Buy } \\
Revenue & $\$ 60,000$ & $\$ 60,000$ \\
Material Costs & 20,000 & 22,600 \\
Employee Costs & 9,000 & 9,000 \\
Machine Costs & 10,000 & 10,000 \\
Occupancy \& Other & 7,000 & 7,000 \\
Profit & $\underline{\$ 14,000}$ & $\underline{\underline{\$ 11,400}}$ \\
VS Profit \% & $23.33 \%$ & $19.00 \%$
\end{tabular}


Note that the buy decision would result in an increase in material costs for the total amount $(\$ 3,800)$ of the contract to purchase, but would cause an offsetting decrease in material costs of $\$ 1,200$ for a net effect of $\$ 2,600$. Employee costs would not be affected because they are considered fixed costs under lean accounting.

Techsan should make the product based on the value stream analysis and the benefit to the company's bottom line is even more apparent than with the traditional analysis. Under the lean accounting analysis, the decision to outsource the part will cost Value Stream 1 over four percent of its profit margin.

\section{CONCLUSIONS}

Lean accounting and the closely related topics of just-in-time inventories and target costing are widely-used accounting methods. Coverage of these topics is sparse in current cost and managerial accounting textbooks. This paper proposed a partial solution to the lack of exposure that students get to the application of lean accounting. The type of examples illustrated above would be very useful learning aids. Students would benefit, not only from their increased understanding of special decisions and make-or-buy decisions, but would also gain a greater understanding of cost assignments, direct costing, and the use of value streams as opposed to traditional segment reporting.

\section{AUTHOR INFORMATION}

Daniel L. Haskin, PhD, CPA, is Professor of Accounting at the University of Central Oklahoma in Edmond, Oklahoma. His primary research interests are in cost and managerial accounting and financial accounting.

\section{REFERENCES}

1. Garrison, R., Noreen, E., Brewer, P. (2010) Managerial Accounting, $13^{\text {th }}$ Edition, McGraw Hill, Irwin.

2. Horngren C., Datar, M., Foster, F, Rajan S, Ittner C. (2090) Cost Accounting: A Managerial Emphasis, $13^{\text {th }}$ Edition, Pearson Prentice Hall.

3. IMA (2006) Accounting for the Lean Enterprise: Major Changes to the Accounting Paradigm, Institute of Management Accountants. 